\title{
Rpl22 is required for IME1 mRNA translation and meiotic induction in S. cerevisiae
}

\author{
Stephen J. Kim and Randy Strich ${ }^{*}$ (])
}

\begin{abstract}
Background: The transition from mitotic cell division to meiotic development in S. cerevisiae requires induction of a transient transcription program that is initiated by Ime1-dependent destruction of the repressor Ume6. Although IME1 mRNA is observed in vegetative cultures, Ime1 protein is not suggesting the presence of a regulatory system restricting translation to meiotic cells.

Results: This study demonstrates that IME1 mRNA translation requires Rpl22A and Rpl22B, eukaryotic-specific ribosomal protein paralogs of the 60S large subunit. In the absence of Rpl22 function, IME1 mRNA synthesis is normal in cultures induced to enter meiosis. However, Ime1 protein production is reduced and the Ume6 repressor is not destroyed in rpl 22 mutant cells preventing early meiotic gene induction resulting in a pre-meiosis I arrest. This role for Rpl22 is not a general consequence of mutating non-essential large ribosomal proteins as strains lacking Rpl29 or Rpl39 execute meiosis with nearly wild-type efficiencies. Several results indicate that Rpl22 functions by enhancing IME1 mRNA translation. First, the Ime1 protein synthesized in rp/22 mutant cells demonstrates the same turnover rate as in wild-type cultures. In addition, IME1 transcript is found in polysome fractions isolated from rp/22 mutant cells indicating that mRNA nuclear export and ribosome association occurs. Finally, deleting the unusually long $5^{\prime} U T R$ restores Ime1 levels and early meiotic gene transcription in rp/22 mutants suggesting that Rpl22 enhances translation through this element. Polysome profiles revealed that under conditions of high translational output, Rpl22 maintains high free 60S subunit levels thus preventing halfmer formation, a translation species indicative of mRNAs bound by an unpaired $40 S$ subunit. In addition to meiosis, Rpl22 is also required for invasive and pseudohyphal growth.
\end{abstract}

Conclusions: These findings indicate that Rpl22A and Rpl22B are required to selectively translate IME1 mRNA that is required for meiotic induction and subsequent gametogenesis. In addition, our results imply a more general role for Rpl22 in cell fate switches responding to environmental nitrogen signals.

Keywords: Translation, Differentiation, Meiosis, Ribosome

\section{Background}

The budding yeast $S$. cerevisiae chooses alternative cell fates based on cell type and environmental cues. For example, in response to poor nitrogen sources, haploid and diploid yeast will undergo a dimorphic switch leading to invasive or pseudohyphal growth, respectively. The switch to pseudohyphal growth requires Ras signaling through Protein Kinase A and is inhibited in response to available nitrogen by Tor1 kinase activation [1-4].

*Correspondence: strichra@rowan.edu

Department of Molecular Biology, Rowan University School

of Osteopathic Medicine, Two Medical Center Dr., Stratford, NJ 08055, USA
Similarly, meiotic induction occurs only in diploid cells deprived of nitrogen and a fermentable carbon source [5]. The switch from mitotic to meiotic cell divisions requires expression of $I M E 1$, which induces the meiotic transcription program by binding and triggering the destruction of the Ume6 repressor [6]. Interestingly, Ime1 is also required for pseudohyphal growth [7] suggesting that the regulatory pathways controlling these two processes exhibit some degree of overlap. IME1 transcription is controlled by a complex and extensive set of cis-acting promoter elements that respond to cell type, carbon and nitrogen signals $[8,9]$. 
In addition to transcriptional control, IME1 mRNA translation is restricted to meiosis although specific mechanisms were not identified [10, 11]. Many translational control mechanisms in eukaryotic cells operate during translation initiation focusing on the formation of a stable pre-initiation complex. Once a stable complex is formed between the mRNA, the 40S subunit and the initiator tRNA, the catalytic $60 \mathrm{~S}$ large subunit associates with the small subunit to form the functional $80 \mathrm{~S}$ complex capable of translation [12, 13]. Following formation of a stable pre-initiation complex, translation can still be inhibited through other mechanisms. For example, the presence of short, upstream open reading frames (uORFs) before the protein encoding initiating AUG causes ribosome stalling and disassociation [14, $15]$.

The roles that ribosomal proteins (RPs) themselves play in regulating translation initiation are less well understood. The ribosome is composed of an rRNA core bound by many RPs that play essential structural roles for ribosome assembly and function [16-18]. Of the 78 ribosomal protein families in eukaryotes, 34 are also found in prokaryotic ribosomes, 67 in archaea [18] leaving only 11 families that are specific to eukaryotic cells [19]. Despite the critical role of translation for cellular function, 14 RPs in yeast are not essential for viability indicating that not all ribosomal proteins serve a basic translation function [18].

One of the non-essential RPs only found in eukarya is the large subunit protein family L22e. RPL22 exist as a paralog pair in yeast $(R P L 22 A, R P L 22 B)$ and mammals (Rpl22, Rpl22-like) [20, 21]. L22e binds a stem-loop on the rRNA [16, 22]. However, it is neither directly at the interface of the ribosomal subunits, nor does it play a structural role in organizing the protein exit channel [16, 17]. The murine Rpl22 is not essential for viability but is required for the differentiation of $\alpha \beta$ T-cells in mice and hematopoietic stem cell emergence in zebrafish indicating it plays a more specialized role in cell fate decisions $[23,24]$. Another group has shown differential expression of Rpl22 and Rpl22-like, the latter of which is alternatively spliced in Drosophila spermatocytes [25]. Interestingly, Rpl22 inhibits the expression of Rpl22-like1 in mice suggesting antagonistic functions for these proteins [20]. The current study describes a role of Rpl22 in mediating cell fate decisions in budding yeast. Although a modest defect is observed in mitotic cell division, loss of Rpl22 function results in significant defects in both pseudohyphal growth and execution of meiotic divisions. The latter phenotype is due to the requirement of Rpl22 in translating the mRNA of the IME1 meiotic inducer. These results identify a specific translation role for Rpl22 during yeast cell fate decisions.

\section{Methods}

\section{Strains and plasmids}

Strain genotypes are listed in Table 1. Haploid rpl22A $\triangle$ and rpl22BA strains were generated by transforming in PCR amplified KanMX cassettes from the Research Genetics collection of nonessential gene deletions into haploid yeast through homologous recombination. Deletion of both paralogs was accomplished through mating, and subsequent tetrad dissection. Homozygous diploids were generated by introducing $H O$ expressing plasmids. The triple hemagglutinin (3HA) tagged IME1 allele was constructed by transforming in linearized pSK17, which contains the last $500 \mathrm{bp}$ of the IME1 ORF in frame with $3 \mathrm{HA}$, and the native $3^{\prime} \mathrm{UTR}$ on pRS306 [26]. The insertion was counter-selected on 5-fluororotic acid (5-FOA) to loop out the plasmid backbone. Individual isolates that retained the epitope tag were confirmed by sequence analysis of genomic PCR fragments. Similarly, the IME1 $5^{\prime}$ UTR was chromosomally deleted by transformation with pSK18, which has the IME1 locus from $-1 \mathrm{~kb}$ to +500 , but lacking $180 \mathrm{bp}$ in the $5^{\prime} \mathrm{UTR}$ in pRS306. The final deletion was also generated by counter selection on 5 -FOA and verified by genomic sequencing.

\section{Media and phenotypic assays}

Cultures were grown in rich YPDA (2\% dextrose, $2 \%$ peptone, $1 \%$ yeast extract supplemented with $10 \mathrm{mg} / \mathrm{l}$ adenine). Plasmid selection was maintained in strains using synthetic dextrose (SD) medium containing $0.17 \%$ yeast nitrogen base without amino acids, $0.5 \%$ ammonium sulfate, $2 \%$ dextrose. Pre-sporulation growth was conducted in either YPA (K acetate (1\%) substituted for dextrose in YPDA) or synthetic acetate (SA, $0.17 \%$ yeast nitrogen base without amino acids, $0.5 \%$ ammonium sulfate, $2 \% \mathrm{~K}$ acetate). Liquid sporulation medium (SPM, $2 \% \mathrm{~K}$ acetate supplemented with uracil) was utilized for meiotic timecourse experiments. Invasive growth assays were performed by streaking cells on to YPDA agar plates, incubated for 3 days at $30{ }^{\circ} \mathrm{C}$ then washed with a gentle stream of water, while clearing cells on the surface with a gloved hand [3]. Pseudohyphal growth was assayed by streaking wild type or rpl22 diploid SK1 cells for single colonies onto synthetic, low-ammonia, dextrose (SLAD) agar plates followed by incubation for 5 days at $30{ }^{\circ} \mathrm{C}[4,7]$. Meiotic timecourse experiments were conducted with cells grown to mid-log phase in YPA or synthetic acetate (SA), washed in water, and resuspended in sporulation medium (SPM) as previously described [27]. Nuclear divisions were monitored by fixing cells with $70 \%$ ethanol at $4^{\circ}$, washed twice with water, then stained for $15 \mathrm{~min}$ with $1 \mu \mathrm{g} / \mathrm{ml} \mathrm{4'}$ 4 $^{\prime} 6^{\prime}$-diamidino-2'-phenylindole (DAPI). The cells were washed twice with water and visualized by fluorescence microscopy. 
Table 1 Strains used in this study

\begin{tabular}{|c|c|c|}
\hline Strain & Genotype $^{a}$ & Reference \\
\hline RSY333 & MATa cyh2 $2^{R}-z$ ho::LYS2 leu2::.hisG lys2 trp 1::hisG ura3 & [6] \\
\hline RSY335 & MATa/MATa cyh2 $2^{\mathrm{R}}-z$ ho::LYS2 leu2::hisG lys2 trp $1:$ hisG ura3 & [27] \\
\hline RSY1446 & MATa cyh2 $2^{R}-z$ ho::LYS2 leu2::hisG lys2 trp 1::hisG ura3 rpl22B::KANMX & This study \\
\hline RSY1479 & MATa cyh2 $2^{R}-z$ ho::LYS2 leu2:: hisG lys2 trp 1::hisG ura3 rpl22A::KANMX & This study \\
\hline RSY1483 & 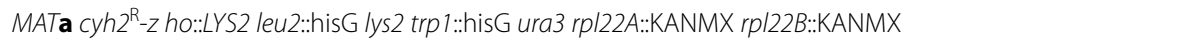 & This study \\
\hline RSY1559 & MATa/MATa cyh2 $2^{R}-z$ ho::LYS2 leu2:::hisG lys2 trp 1::hisG ura3 rpl22A::KANMX & This study \\
\hline RSY1560 & MATa/MATa cyh2 $2^{R}-z$ ho::LYS2 leu2::hisG lys2 trp $1::$ hisG ura3 rpl22B::KANMX & This study \\
\hline RSY1561 & MATa/MATa cyh2 $2^{\mathrm{R}}$-z ho:::LYS2 leu2:::hisG lys2 trp1::hisG ura3 rpl22A::KANMX rp/22B::KANMX & This study \\
\hline RSY1833 & MATa/MATa cyh2 $2^{\mathrm{R}}-z$ ho::LYS2 leu2::hisG lys2 trp1::hisG ura3 IME1::3HA & This study \\
\hline RSY1839 & MATa/MATa cyh2 $2^{\text {R }}$-z ho::LYS2 leu2::hisG lys2 trp 1::hisG ura3 rpl22A::KANMX rpl22B::KANMX IME1::3HA & This study \\
\hline RSY1991 & MATa/MATa cyh2 ${ }^{R}-z$ ho:::LYS2 leu2::hisG lys2 trp 1::hisG ura3 5'UTRA-IME1:3HA & This study \\
\hline RSY1993 & MATa/MATa cyh2 ${ }^{\mathrm{R}}-\mathrm{z}$ ho::LYS2 leu2::hisG lys2 trp 1::hisG ura3 rpl22A::KANMX rpl22B::KANMX 5'UTRA-IME1::3HA & This study \\
\hline RSY883 & MATa lys2 lys2 trp 1::hisG ura3 LYS2::ho & This study \\
\hline RSY877 & MATa/MATa lys2 lys2 trp 1::hisG ura3 LYS2::ho & This study \\
\hline RSY1823 & MATa lys2 trp 1::hisG ura3 LYS2::ho rp/22A::KANMX rp/22B::KANMX & This study \\
\hline RSY1826 & MATa lys2 trp 1::hisG ura3 LYS2::'ho rp/22A::KANMX rp/22B::KANMX & This study \\
\hline RSY1997 & MATa/MATa cyh2 $2^{\mathrm{R}}$-z ho::LYS2 leu2::hisG lys2 trp 1::hisG ura3 rpl39::KANMX & This study \\
\hline RSY2003 & MATa/MATa cyh2 $2^{\mathrm{R}}$-z ho::LYS2 leu2::hisG lys2 trp 1::hisG ura3 rpl29::KANMX & This study \\
\hline
\end{tabular}

${ }^{a}$ All markers shown are homozygous in the MATa/MATa strains unless indicated

\section{Protein extraction, western blotting, cycloheximide chase assay}

Approximately $5 \times 10^{7}$ cells were treated with $0.2 \mathrm{M}$ sodium hydroxide, with subsequent extraction in Laemilli buffer accompanied by glass bead lysis [28]. $1 \times 10^{7}$ cell equivalents were loaded for each sample. Proteins were separated by $10 \%$ SDS-PAGE, transferred to PVDF membranes and blots were probed with antiHA (12CA5, Roche), anti-Tub1p (Developmental Studies Hybridoma Bank, University of Iowa), poly-clonal anti-Ume6 or anti-Pgk1p (Invitrogen) monoclonal antibodies and visualized using AP conjugated anti-mouse secondary antibody and the CDP-Star system. Cycloheximide $(\mathrm{CHX})$ chase assays were performed essentially as described [29].

\section{In vivo translation analysis}

Exponentially growing cells in rich media were depleted of their methionine and cysteine stores through growth in defined medium lacking these amino acids. After an hour of incubation, $125 \mu \mathrm{Ci}$ of ${ }^{35} \mathrm{~S}$ labeled methionine and cysteine were introduced to the medium and incubated at $30{ }^{\circ} \mathrm{C}$. Samples were taken, washed, and frozen in liquid nitrogen every $5 \mathrm{~min}$ for $20 \mathrm{~min}$. The proteins were extracted in Laemmli buffer and $1 \times 10^{7}$ cell equivalents were either precipitated using methanol and chloroform to remove unincorporated label to measure total isotope incorporation, or run on a polyacrylamide gel for radiography.

\section{Polysome profiles}

Polysome profiles were performed for each of the given nutritional conditions, as described [30]. Cultures were treated with $100 \mu \mathrm{g} / \mathrm{ml}$ (final concentration) cycloheximide. Harvested cells were washed in lysis buffer in the presence of cycloheximide and heparin, and lysed using glass beads at $4^{\circ} \mathrm{C}$. Lysates were clarified with sequential centrifugation $(5 \mathrm{~K} \times g, 5 \mathrm{~min} ; 13 \mathrm{~K} \times g, 10 \mathrm{~min})$ and approximately $200 \mu \mathrm{g}$ of total RNA was loaded on 15-50\% sucrose gradients. Gradients were centrifuged for $4.25 \mathrm{~h}$ at $160 \mathrm{~K} \times g$. Gradients were analyzed using a continuous flow cuvette. For mRNA analysis of polysomes, wild-type and rpl22 $\Delta$ cells were grown in $50 \mathrm{ml}$ of YPA and shifted to $10 \mathrm{ml}$ of sporulation medium for $9 \mathrm{~h}$. A small sample was taken for total RNA with the remaining cells treated with cycloheximide $(100 \mu \mathrm{g} / \mathrm{ml}$ for $5 \mathrm{~min})$, crosslinked (1\% formaldehyde for $5 \mathrm{~min}$ ), then the crosslinking quenched with glycine $(250 \mathrm{mM})$. The cells were harvested by centrifugation and snap frozen in liquid nitrogen. Lysates were prepared, centrifuged through a sucrose density gradient, and fractionated as previously described [31]. Fractions were treated with $1 \%$ SDS, $16.6 \mathrm{mM}$ EDTA, and $0.1 \mathrm{mg} / \mathrm{ml}$ proteinase $\mathrm{K}$, and incubated at $42{ }^{\circ} \mathrm{C}$ for $1 \mathrm{~h}$, then $65{ }^{\circ} \mathrm{C}$ for $1 \mathrm{~h}$ to reverse crosslinks. Fractions were then extracted with an equal volume of phenol-chloroform-isoamyl alcohol (25:24:1), and precipitated with an equal volume of isopropyl alcohol. The RNA pellets recovered were washed twice in $70 \%$ ethanol, and equal proportions of each fraction were analyzed by Northern blot. 
Five microgram each of total RNA and crude lysate were loaded alongside RNA recovered from the sucrose density gradient. Membranes were probed for IME1 and ENO1 as described above, and imaged on a Typhoon Phosphor Imager (GE Healthcare).

\section{Northern blotting and qRT-PCR}

Frozen cell pellets from meiotic time courses were lysed with glass beads and phenol-chloroform extracted as previously described [6]. RNA pellets were resuspended in DEPC treated $\mathrm{dH}_{2} \mathrm{O}$, quantitated, and equal masses were run on $1.2 \%$ agarose formaldehyde gels. Separated RNA was blotted using capillary action and probed for the genes of interest indicated. Probes used were gel purified PCR products or restriction digests of the ORF of the genes of interest and randomly labeled using Klenow and $\alpha-{ }^{32} \mathrm{P}$ labeled dCTP. qRT-PCR was performed with similarly extracted RNA. RNA was reverse transcribed using AMV-RT (NEB), and amplified using primer pairs of the genes of interest using Power Sybr (AppliedBiosystems), listed in Table 2.

25S:18S rRNA ratios were determined for logarithmic cultures or $9 \mathrm{~h}$ following the shift to SPM. Total RNA dilutions $(2,1$, or $0.5 \mu \mathrm{g})$ from each condition were analyzed by Northern blot probing with the Y503 and Y500 rRNA probes as described [31]. The signals were quantitated by phosphorimager and the $25 \mathrm{~S}: 18 \mathrm{~S}$ ratios calculated for each condition. Ratios were averaged for each condition and normalized to the wild-type rich growth (YPD) value. The relative error was propagated from the standard deviation obtained from each averaged ratio.

\section{Results}

\section{Rpl22 is a non-essential ribosomal protein}

In both zebra fish and mice, L22 is not essential for the production of adult animals [24]. However, defects in specific developmental pathways were identified. To assess what role, if any, Rpl22 played in differentiation

\section{Table 2 qRT-PCR primers used in this study}

\begin{tabular}{ll}
\hline Primer & Name sequence \\
\hline ENO1-F & GCC GCT GCT GAA AAG AAT GT \\
ENO1-R & TGG AGA GGT CTT GGA CTT AGA CAA \\
IME2-F & AAT GTTTTG GGT GAT GCC TCT T \\
IME2-R & TTC TTG GAG TAA AAT CTG GCA TTG \\
NUP85-F & TTC GCG AAG GAG CAT AAT GC \\
NUP85-R & ACA CTT CCA ATT CAT TCA GAA TCG \\
RPL22A-F & CCA AGA CCT TTA CCG TCG ATG T \\
RPL22A-R & AGG AAG CTG GGT CGA AGA C \\
RPL22B-F & GAG TCTTCG ATC CGG CTT CA \\
RPL22B-R & TTC CTA CGG CAC CAT CTA CTT TAAT \\
\hline
\end{tabular}

processes in yeast, either single ( $r p l 22 A \Delta$ or $r p l 22 B \Delta)$ or double $(r p l 22 \Delta)$ strains were constructed. Similar to a previous report [18], Rpl22A and/or Rpl22B function is not required for mitotic cell division in rich medium although the doubling times for the rpl22A $\Delta$ and $r p l 22 \Delta$ double mutant strains were slightly reduced compared to wild type or $r p l 22 B \Delta$ cultures (data not shown). However, we found that $r p l 22 A \Delta$ or $r p l 22 \Delta$ strains were unable to form colonies when incubated at $4{ }^{\circ} \mathrm{C}$ for $24 \mathrm{~h}$ then returned to growth at $25^{\circ}$ (Fig. 1a). To determine whether this phenotype was due to the reduced temperature itself, or the result of a return to growth defect, cultures were incubated at $25^{\circ}$ for 3 days to arrest cell division in stationary phase. The cells were diluted then replated on rich medium and incubated at $25^{\circ}$. This experiment found no difference in the return to growth of any mutant compared to wild type (Fig. 1a, right panel). These results indicate that Rpl22A is required for survival at low temperatures.

To examine this phenotype further, wild type, $r p l 22 A \Delta$, rpl22BA and rpl22 $\Delta$ double mutants were streaked on rich growth medium and incubated at the intermediate temperature of $19{ }^{\circ} \mathrm{C}$ for 4 days. The wild type and rpl22BA strains grew similarly while the $r p l 22 A \Delta$ and double mutant failed to form colonies (Fig. 1b, left panel). To determine whether these strains were growth arrested or lost viability, the same plates were then placed at $25^{\circ} \mathrm{C}$ for 2 days and images obtained. In this experiment, growth was observed for the rpl22A $\Delta$ and double mutant (right panel) indicating that a mild cold shock is sufficient to arrest cell division but not kill the cell while a more severe reduction in temperature results in cell death.

The phenotypic differences observed between $r p l 22 A \Delta$ and $r p l 22 B \Delta$ mutants may be explained by the finding that $R P L 22 A$ is transcribed at much higher levels than $R P L 22 B$ [32]. Another contributing factor could also be the regulation of one paralog by the other [33]. Therefore, we examined mRNA levels of each gene in logarithmic cultures by qRT-PCR. RPL22A and RPL22B mRNA levels were first standardized to control transcripts (NUP85 and ENO1). Our control genes were expressed at relatively comparable levels, regardless of the gene deletion (Fig. 1c). In the absence of RPL22A, RPL22B expression increased fourfold while deletion of $R P L 22 B$ did not affect $R P L 22 A$ mRNA levels. These results indicate that loss of one RPL22 allele does not adversely impact the activity of the other. These findings are consistent with the model that elevated Rpl22A expression levels represent a major cause for our observed phenotypic differences.

Rpl22 is required for invasive and pseudohyphal growth As described above, Rpl22 regulates metazoan cell differentiation pathways. Similarly, yeast exhibit several 


\section{a}

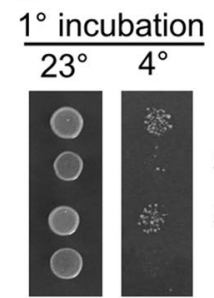

$23^{\circ}$

$\overline{2^{\circ} \text { incubation }}$

C

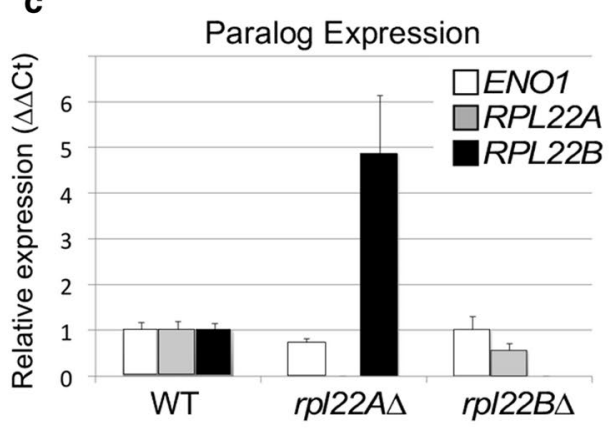

b

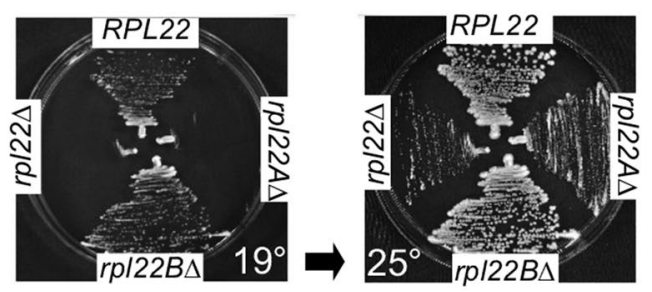

d
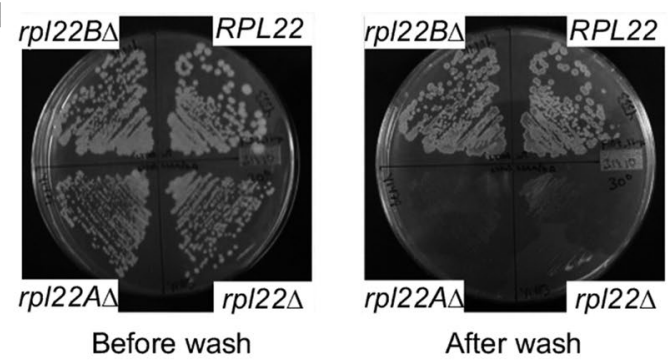

e
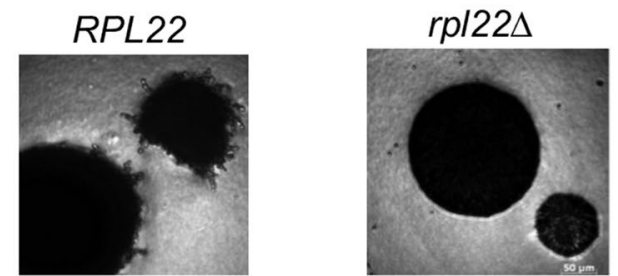

Fig. 1 Rpl22 is a nonessential protein required for hyphal growth. a Wild type (RSY333), rp/22A (RSY1479), rpl22B (RSY1446) and rp/22 $\triangle$ double mutant (RSY1483) cultures were incubated at the indicated temperatures for $24 \mathrm{~h}$ in rich (YPD) liquid culture then spotted onto rich agar plates and incubated at $23^{\circ}$ (left panel). The same cultures were grown in rich medium at $23^{\circ}$ for 5 days, then a dilution series was spotted on rich agar and incubated at $23^{\circ}$ for 2 days. $\mathbf{b}$ The strains described in a were streaked on YPD agar plates and incubated at $19^{\circ} \mathrm{C}$ for 4 days (left panel), then $30^{\circ} \mathrm{C}$ for 2 days (right panel). $\mathbf{c}$ Wild type (RSY333), rpl22A $\triangle$ (RSY1479) and rpl22BA (RSY1446) cultures were grown to mid-log and total RNA preparations were subjected to qRT-PCR analysis. RPL22A and RPL22B mRNA levels were normalized to NUP85 in wild type then analyzed in each single mutant. ENO1 mRNA levels were quantified as a RNA concentration control. The results are referenced to wild type levels \pm SEM $(n=3)$. $\mathbf{d}$ Haploid strains described in a were streaked on rich growth medium for 2 days (left panel), then subjected to a stream of water, the re-incubated for $24 \mathrm{~h}$ (right panel). e SK1 derived diploid wild type (RSY877) and rpl22 (RSY1823) double mutant cells were assayed for pseudohyphal growth by microscopy ( $\times 60$ final magnification)

alternative cell fates controlled by cell type and environmental cues. A nitrogen-diminished environment triggers changes in cell cycle and cell shape in haploid or diploid cells termed invasive or pseudohyphal growth, respectively [7]. Therefore, we investigated a role for RPL22 in these processes. First, we determined whether $\mathrm{Rp} 22 \mathrm{~A}$ and/or Rpl22B were required for invasive growth. Haploid wild-type, $r p l 22 A \Delta$, $r p l 22 B \Delta$, and $r p l 22 \Delta$ double mutant cells were grown on rich solid medium then the plate was washed with water. Cells embedded in the agar due to invasive growth will be resistant to washing. Cells lacking RPL22A or both paralogs were unable to significantly penetrate the agar, while wild type and rpl22BA cells were embedded (Fig. 1d). These results indicate that Rpl22A is required for invasive growth. Next, we tested the requirement of Rpl22 for pseudohyphal growth by generating diploid strains lacking both RPL22 paralogs in the SK1 strain background. This background was chosen as it exhibits a robust pseudohyphal growth phenotype. Wild type and rpl22A double mutant cells were streaked on SLAD plates which contain limiting nitrogen, incubated at $30{ }^{\circ} \mathrm{C}$ for 4 days. Microscopic examination revealed a radial growth from the center of in wild-type colonies. Conversely, no rpl $22 \Delta$ cells exhibited this phenotype (500 cells examined, Fig. 1e). These results indicate that Rpl22 plays a second role in the switch from budding to hyphal forms of cell division. Taken together, these results indicate that Rpl22 plays an important role in the morphogenic switches that respond to a reduced nitrogen environment. 
Rpl22 is required for the execution of meiotic development Similar to filamentous growth, entry into meiosis is controlled by both cell type and exogenous signals. To test whether Rpl22 is required for meiosis and subsequent spore formation, wild type, $r p l 22 A \Delta$, rpl22B $\Delta$ and $r p l 22 \Delta$ diploids were grown to mid-log phase in rich growth medium containing the non-fermentable carbon source acetate (YPA). These cultures were harvested, washed, then transferred to sporulation medium (SPM) and time points taken. The percentage of each population able to undergo either one or both meiotic nuclear divisions was determined by DAPI staining and fluorescence microscopy. In this experiment, meiotic nuclear divisions began by $12 \mathrm{~h}$ following transfer to SPM in the wild-type culture reaching $\sim 60 \%$ by $24 \mathrm{~h}$ (Fig. $2 \mathrm{a}$, quantitated in Fig. $2 \mathrm{~b}$ ). The $r p l 22 A \Delta$ strain exhibited a significant reduction $(\mathrm{p}=0.001)$ in bi- and tetra-nucleated cells compared to wild type while rpl22BA cells showed a modest but significant $(\mathrm{p}=0.05)$ loss in cells executing one or both meiotic divisions. However, only $2 \%$ of rpl $22 \Delta$ double mutant cells were able to complete either round of division. These results indicate that Rpl22 is required for execution of the meiotic nuclear divisions.

To determine if this meiotic role for Rpl22 was a general property of non-essential ribosomal proteins, two additional large subunit proteins, Rpl39 and Rpl29, were analyzed. Rpl29 localizes to the 40S interaction face and is required for efficient subunit association [34]. Conversely, Rpl39 resides near the peptide exit channel [35]. Finally, these nonessential RP genes were chosen as their deletion reduced growth rates to a level similar to rpl22A $\triangle$ mutants [18]. Unlike RPL22, RPL39 and RPL29 are not duplicated so only single $r p l 39 \Delta$ or $r p l 29 \Delta$ diploids were constructed. Their ability to undergo meiosis was assessed as just described. These experiments revealed a modest but significant $(\mathrm{p}=0.03, \mathrm{n}=3-5)$ difference between wild type and the rpl394 diploid while no difference was observed in rpl29 $\Delta$ cells (Fig. 2b). How-

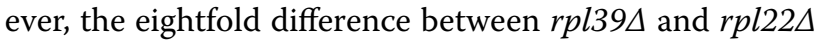
mutant culture meiotic efficiencies indicates that a severe meiotic defect is not a general feature of deleting nonessential ribosomal genes.

\section{Rpl22 is required for IME1 mRNA translation}

The inability of $r p l 22 \Delta$ double mutants to undergo meiosis I or meiosis II could be due to a failure to exit the mitotic cell cycle or represent an early meiotic arrest prior to anaphase I. To address this question, wild type and $r p l 22 \Delta$ double mutant were induced to enter meiosis and Northern blot analysis was performed on total RNA prepared from different time points. The resulting blots were probed for mRNAs transcribed at different stages of meiotic development. In the wild-type culture, a normal
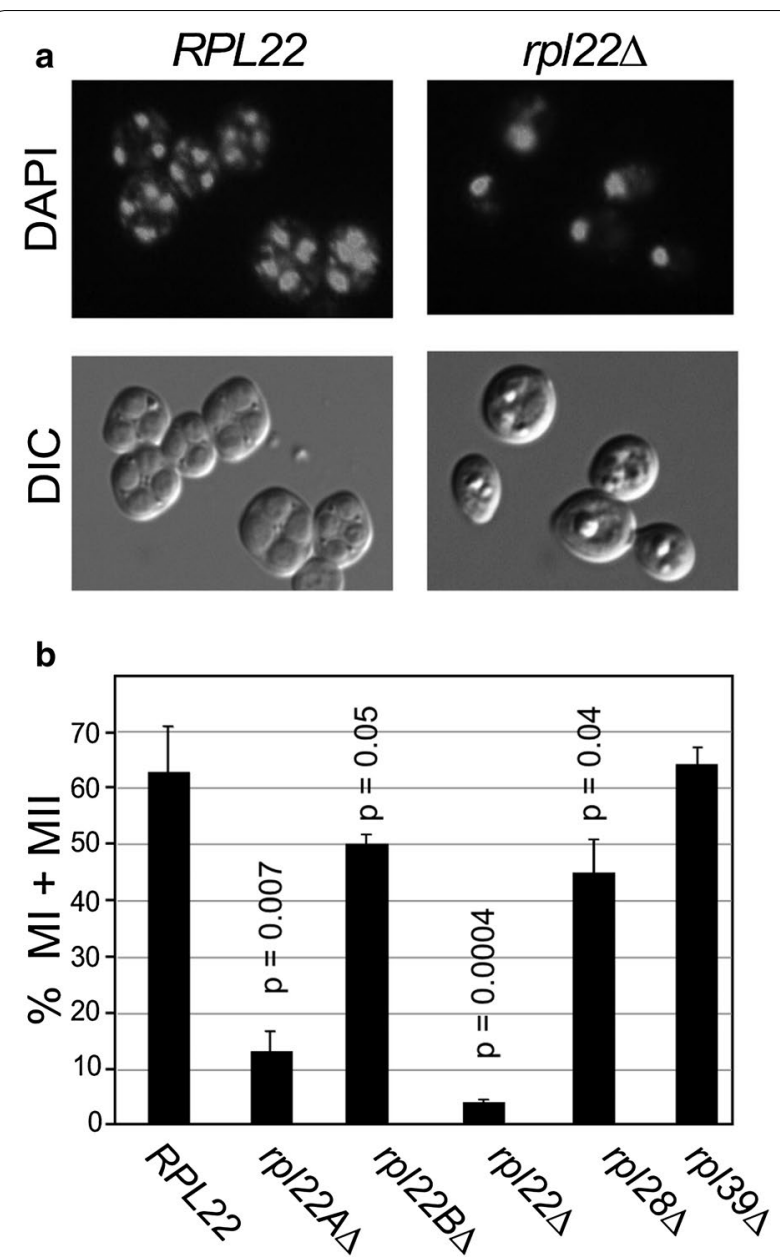

Fig. 2 Rpl22 is required for execution of meiotic nuclear divisions. a Wild type (RSY335) and rp/22 $\Delta$ double mutant (RSY1561) cultures were grown in rich acetate (YPA) then shifted to sporulation medium (SPM) for $24 \mathrm{~h}$ and monitored for the production of bi-nucleated and tetranucleated cells by fluorescence microscopy of DAPI stained cells. $\mathbf{b}$ The percent of bi- or tetra-nucleated cells in the population is shown for the strains described in a and rp/22A $\triangle$ (RSY1559), rp/22B

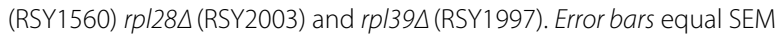
$p$ values compared to wild type are indicated when significant differences were observed $(n \geq 3)$

transcription profile was observed with the transient transcription of meiotic inducer IME1, as well as $I M E 2$, NDT80, and SPS4, members of the "early", "early-middle" and "middle" expression classes, respectively (Fig. 3a). However, although $r p l 22 \Delta$ cells robustly expressed IME1 mRNA, the levels of IME2, NDT80, and SPS4 transcripts were at or below the limits of detection. These results indicate that rpl22 $\Delta$ mutants enter the meiotic program but arrest prior to the transcription of the early meiotic gene class.

Early meiotic gene induction requires the destruction of the transcriptional repressor Ume6 $[6,36]$. The lack of 


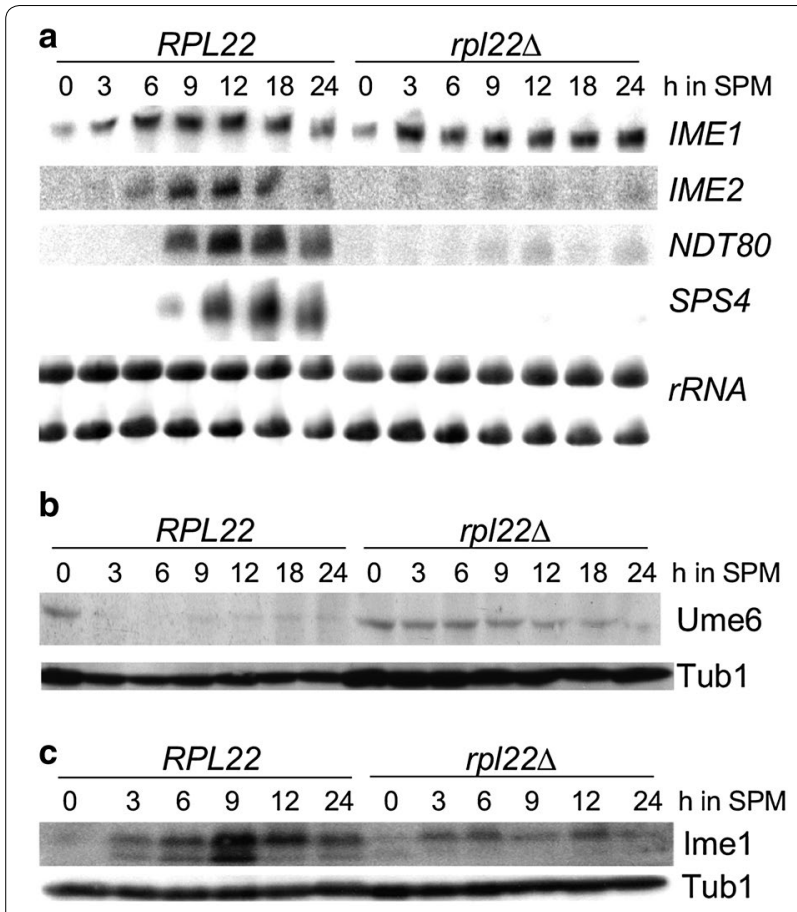

Fig. 3 Rpl22 is required for meiotic accumulation of Ime1. a Wild type (RSY333) and rp/22 $\triangle$ (RSY1561) double mutant cells were grown to mid-log phase in YPA and shifted to SPM and samples taken at the times indicated. Total RNA preparations were subjected to Northern blot analysis and probed for the IME1, early (IME2), early-middle (NDT80), and middle (SPS4) meiotic genes as indicated. Ethidium bromide stained rRNA served as the loading control. b Western blot analysis of protein extracts prepared from the same meiotic timecourse described in A was probed for endogenous Ume6. Tub1 levels served as a loading control. c Wild type (RSY1833) and rpl22 $($ RSY1839) double mutant diploids expressing IME1-3HA were subjected to a meiotic timecourse experiment. Protein extracts prepared from the indicated timepoints were probed for the presence of Ime1-3HA. The blots were reprobed for Tub1 which served as a loading control

IME2 transcript accumulation suggested that the Ume6 repressor is not destroyed in the $r p l 22 \Delta$ mutant. To test this model, wild type and $r p l 22 \Delta$ double mutant diploids were subjected to a meiotic timecourse experiment and endogenous Ume6 levels were monitored by Western blot analysis of total protein extracts. As observed previously [6], Ume6 levels are reduced below the limits of detection in the wild-type culture shortly after transfer to SPM (Fig. 3b). However, Ume6 levels remained constant in the rpl22 $\Delta$ mutant strain until late in the timecourse. These results indicate that $\mathrm{Rpl} 22$ is required for Ume6 destruction and subsequent meiotic progression.

We previously reported that Ime1 association is required for the $\mathrm{APC} / \mathrm{C}^{\mathrm{Cdc} 20}$ ubiquitin ligase-directed proteolysis of Ume6 $[6,36]$. Therefore, we next examined Ime1 levels during meiosis in a wild type and $r p l 22 \Delta$ double mutant strains. The IME1 allele was chromosomally tagged with three copies of the hemagglutinin (3HA) epitope to allow Ime1 detection by Western blot analysis. Sporulation kinetics and efficiency were indistinguishable between the wild-type strain expressing Ime1 or Ime13HA indicating that the tagged allele is functional (data not shown). In the wild-type strain, the Ime1-3HA signal was detected by $3 \mathrm{~h}$ following transfer to SPM with peak expression occurring at $9 \mathrm{~h}$ (Fig. 3c). In the rpl22 $\Delta$ cells, Ime1-3HA was detected at $3 \mathrm{~h}$ but its levels remained flat throughout the timecourse and did not exhibit a spike in expression. These results suggest that Rpl22 is required for normal Ime1 accumulation, which in turn leads to Ume6 destruction and meiotic progression.

\section{Rpl22 is required for efficient IME1 mRNA translation}

Our results indicate that Rpl22 is required for Ime1 accumulation in meiotic cells. There are several mechanisms that could explain this result. First, Rpl22 may have a general impact on translation. To test this possibility, translation by quantified by measuring ${ }^{35} \mathrm{~S}$-Met and ${ }^{35} \mathrm{~S}$ Cys incorporation. Isolates of wild type and rpl22 $\Delta$ cells were starved of methionine and cysteine for an hour. ${ }^{35} \mathrm{~S}$ labeled methionine and cysteine were added to the medium and samples were collected at the times indicated (Fig. 4a). Extracted proteins were precipitated and the radioactivity counted by scintillation spectroscopy. By 10 min following addition of the labeled amino acids, a small reduction in ${ }^{35} \mathrm{~S}$ incorporation was observed in rpl22 $\Delta$ double mutants compared to wild type that continued throughout the timecourse. These differences were not significant and indicate, consistent with the modest reduction in growth rates, that $\mathrm{Rpl} 22$ is not required for bulk translation. Next, we tested whether Rpl22 is required to maintain Ime1 protein stability. To examine this question, Ime1 turnover was monitored using cycloheximide ( $\mathrm{CHX}$ ) translation shut off experiments. CHX was added to wild-type and rpl22 2 diploid cultures $9 \mathrm{~h}$ following transfer to SPM. Timepoints were taken and protein extracts prepared from these samples were subjected to Western blot analysis. Quantitation of the Ime1 signal revealed a similar decline in protein levels (Fig. 4b). These results indicate that Rpl22 does not control Ime1 turnover.

Our results indicate that Rpl22 does not control IME1 transcription or Ime1 protein stability. These findings point to translation as a potential explanation for reduced Ime1 accumulation in the $r p l 22 \Delta$ strains. Translation defects can be due to failure of the mRNA to successfully exit the nucleus and associate with the ribosome or defects in the translation process itself. To test these possibilities, we probed for the presence of IME1 mRNA in ribosome fractions. Cultures taken $9 \mathrm{~h}$ following transfer 


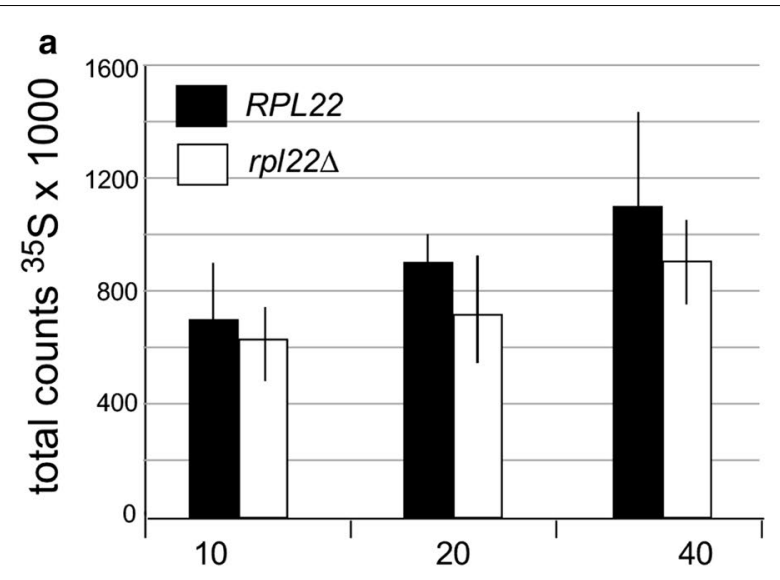

C

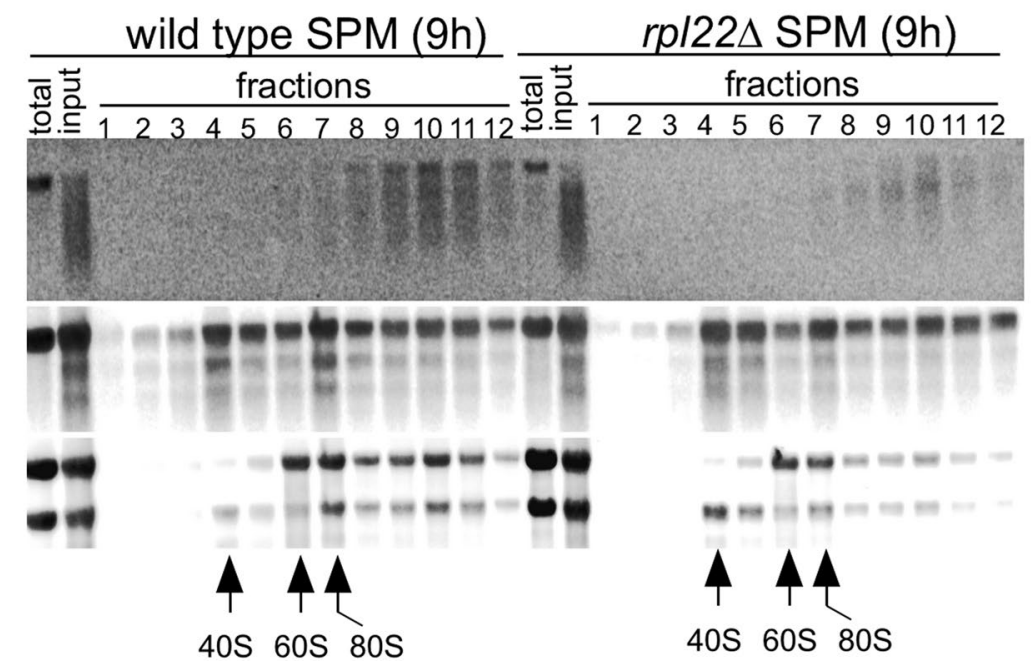

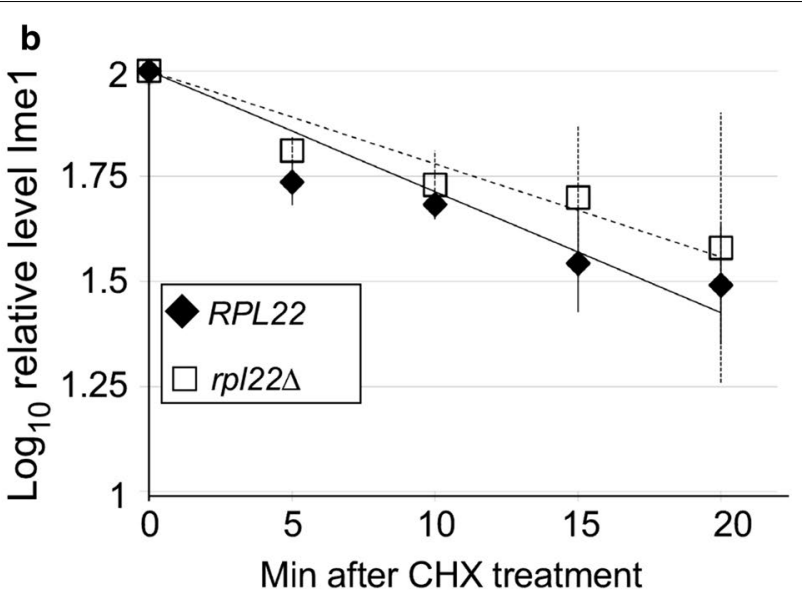

d

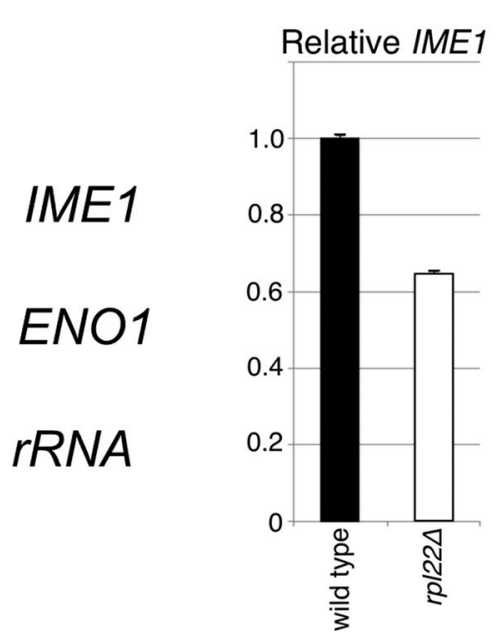

Fig. 4 Rpl22 enhances IME1 mRNA translation. a Incorporation of ${ }^{35} \mathrm{~S}$ methionine and cysteine into bulk protein was monitored by scintillation spectroscopy in wild type (RSY333) and rp/22 $\triangle$ double mutant (RSY1483) at the indicated times (min) following addition of radioactive amino acids to starved cultures. Error bars represent SEM from two experiments with two independent isolates each. b Wild type (RSY333) and rp/22 (RSY1561) double mutant cells were induced to enter meiosis and cycloheximide was added at $9 \mathrm{~h}$ following transfer to SPM. Timepoints were taken after addition of $\mathrm{CHX}$ at the times indicated. Ime1-3HA specific chemiluminescence signals were detected by Western blot analysis and quantified by CCD camera. Graph shows the averaged results from two independent experiments. Error bars indicate SEM. c Polysomes were isolated from wild type and $r$ p/22 $\triangle$ double mutant cultures $9 \mathrm{~h}$ following transfer to SPM. Total RNA isolated from the indicated fractions was subjected to Northern blot analysis with the indicated probes. The position of the ribosomal subunits and monosomes are indicated. Total RNA lane indicates samples prepared directly from harvested cells. Input represents total RNA isolated from polysome extracts prior to fractionation. d The relative amounts of IME1 mRNA in total RNA preparations from wild type (RSY333) and rp/22 (RSY1561) double mutant cells were determined by qRT-PCR. The graph shows the results and SEM from three technical replicates from one experiment

to SPM and treated with a combination of CHX and formaldehyde to stall and crosslink ribosomes to mRNA. This arrest protocol was employed as we discovered that conventional $\mathrm{CHX}$ translation arrest resulted in severe IME1 mRNA degradation (data not shown). Total RNA isolated from these polysomes was subjected to Northern blot analysis probing for IME1 mRNA. These studies revealed that IME1 mRNA was still degraded in both wild type and rpl22 $\Delta$ diploids when compared to other control transcripts (ENO1 or rRNA). However, IME1 mRNA was still detected in both wild type and rpl22 $\triangle$ mutant polysome fractions although the levels appeared reduced in the mutant fractions (Fig. 4c). Quantitating the mRNA samples did reveal that IME1 mRNA levels were reduced approximately $40 \%$ in the rpl22 $\Delta$ sample in this experiment (Fig. 4d). Taking this result into consideration, this experiment indicates that $I M E 1 \mathrm{mRNA}$ is associated with polysomes in meiotic $r p l 22 \Delta$ cells. These 
findings suggest that Rpl22 functions following ribosome binding but prior to translation initiation (see "Discussion" section). In addition, these results suggest that IME1 mRNA maybe specifically targeted for degradation on stalled ribosomes.

\section{Rpl22 operates through the IME1 5'UTR to promote translation}

We next sought an underlying mechanism to explain the role of Rpl22 in IME1 mRNA translation. IME1 mRNA is unusual among yeast transcripts for containing a large $230 \mathrm{nt} 5^{\prime} \mathrm{UTR}$, which has been hypothesized to regulate translation [10]. We hypothesized that the long $5^{\prime} \mathrm{UTR}$ may make IME1 mRNA refractory to translation by ribosomes lacking Rpl22. To test this possibility, we genomically deleted $180 \mathrm{nt}$ of the IME1-5'UTR ( $\left.5^{\prime} \mathrm{UTR} \Delta-I M E 1\right)$ in wild-type and rpl22 $2 \Delta$ double mutant cells. This deletion was selected as it maintained the local context of both the transcriptional and translational start sites. We monitored Ime1-3HA protein levels from the wild type or $5^{\prime} \mathrm{UTR} \triangle-I M E 1$ allele during a meiotic time course experiment. As before (Fig. 3c), Ime1 levels were induced at the same time but failed to display stage-specific induction in the rpl22 $\Delta$ strain compared to wild type (top panels, Fig. 5a, quantitated in Fig. 5b). Deleting the 5'UTR lead to earlier Ime1 induction compared to wild type (see $6 \mathrm{~h}$ timepoint, left panels) but both strains exhibited reduced Ime1 levels by $24 \mathrm{~h}$. These results suggest that that the $5^{\prime}$ UTR is not important for neither the initial accumulation of Ime1 nor its down regulation later in development. In the $r p l 22 \Delta 5^{\prime} \mathrm{UTR} \Delta-I M E 1$ strain, Ime1 was fully induced by the 3 -h timepoint and remained elevated throughout the experiment. These results are consistent with a model that the $5^{\prime} \mathrm{UTR}$ inhibits IME1 mRNA translation that is relieved by Rpl22 function. In addition, these results suggest that Rpl22 plays a role in re-establishing repression of Ime1 levels as the culture completes the meiotic program.

Next, we determined whether relieving the $5^{\prime} \mathrm{UTR}$ block to translation was sufficient to restore Ime1 function and complete meiosis in the rpl22 $\Delta$ mutant. First, as an indicator of Ume6 destruction, IME2 mRNA expression was compared in an rpl22 $\Delta$ double mutant diploid harboring either wild type IME1 or the $5^{\prime} \mathrm{UTR} \triangle-I M E 1$ deletion allele. Total RNA was prepared from a meiotic timecourse experiment and IME2 mRNA concentrations were determined by qRT-PCR. As previously described, IME2 mRNA was not induced in rpl22 $\triangle$ cells containing the intact IME1 $5^{\prime} \mathrm{UTR}$ (hatched box, Fig. $5 \mathrm{c}$ ). Although delayed by a timepoint, IME2 mRNA was induced to levels higher in the rpl22S 5'UTR $\triangle$-IME1 mutant (black box) compared to rpl22 IME1 cells. These results indicate that the increase in Ime1 observed in the $5^{\prime} \mathrm{UTR} \Delta-I M E 1$ strain was sufficient to induce Ume6 destruction and subsequent IME2 transcription but not quite to wild-type levels. Interestingly, although Ime1 levels were induced early and stayed elevated in the rpl $22 \triangle 5^{\prime} \mathrm{UTR} \triangle-I M E 1$ cells, the kinetics of IME2 mRNA accumulation were slower than wild type. These results suggest that Rpl22 has a role in IME2 mRNA induction in addition to IME1 mRNA translation.

We next tested whether deletion of the $5^{\prime}$ UTR could rescue the rpl22A sporulation phenotype. In the RPL22 strain, the presence of the $5^{\prime} \mathrm{UTR} \Delta$ allele did not alter sporulation efficiency compared to the intact IME1 allele (Fig. 5d) indicating that the differences in Ime1 expression kinetics do not affect the efficiency of meiotic divisions. In the rpl22 $\Delta$ double mutant, the presence of 5'UTR $\triangle-I M E 1$ allowed a significant increase in sporulation efficiency compared to rpl22A cells harboring wild type $I M E 1$. These results indicate that deleting the $5^{\prime}$ UTR can bypass the meiotic defect in a rpl22 $\Delta$ double mutant. However, the rescue was not to the levels observed in wild type cells. This observation, combined with the IME2 mRNA analysis in the rpl22S 5'UTR $\Delta$ $I M E 1$ strain, suggests that Rpl22 has additional execution points later in meiosis (see "Discussion" section).

\section{Rpl22 is required for normal polysome assembly}

Our results indicate that Rpl22 is required for normal IME1 mRNA translation even though the transcript is found in the polysomes. Therefore, we next determined whether Rpl22 is required for normal polysome assembly. Velocity sedimentation gradients were utilized to generate polysome profiles of logarithmically growing wild type and rpl22 mutant cells in rich dextrose medium. The wild-type profile exhibited the expected monosome (80S) and polysome peaks, as well as free small (40S) and large (60S) subunits (Fig. 6a). A similar profile was observed for $r p l 22 B \Delta$ mutant extracts (Fig. 6c). However, several differences in the polysome profile were observed in $r p l 22 A \Delta$ or the $r p l 22 \Delta$ double mutant strains (Fig. 6b, $\mathrm{d}$, respectively). First, we found that $r p l 22 \Delta$ or $r p l 22 A \Delta$ cells exhibited reduced 60S:40S particle ratio compared to wild type (quantified in Fig. 6f). In addition, these profiles exhibited doublets at the $80 \mathrm{~S}$ peak and each subsequent peak in the polysome fraction. These peaks are indicative of "halfmer" formation that is usually diagnostic for a bound $40 \mathrm{~S}$ particle that is not stably bound by the 605 subunit [37-39]. Taken together, these results indicate that Rpl22 plays an important role in $60 \mathrm{~S}$ subunit assembly and/or its ability to stably associate with the 40S particle.

We hypothesized that defects in polysome formation may explain the observed lack of Ime1 accumulation. Therefore, we performed polysome analysis on 

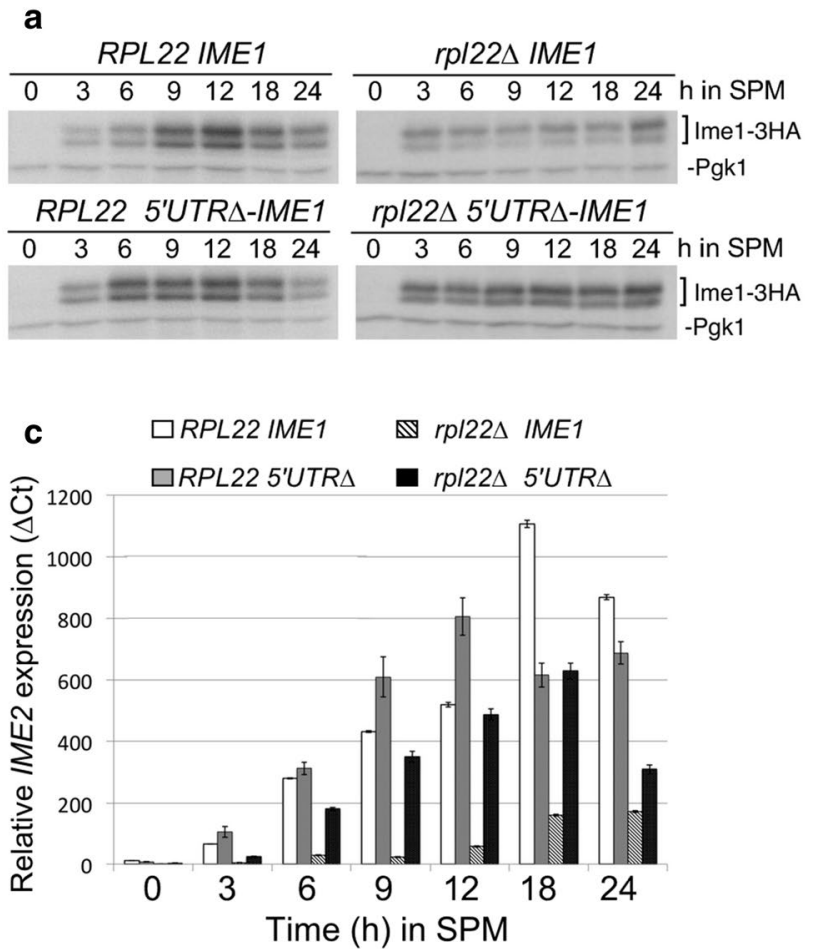
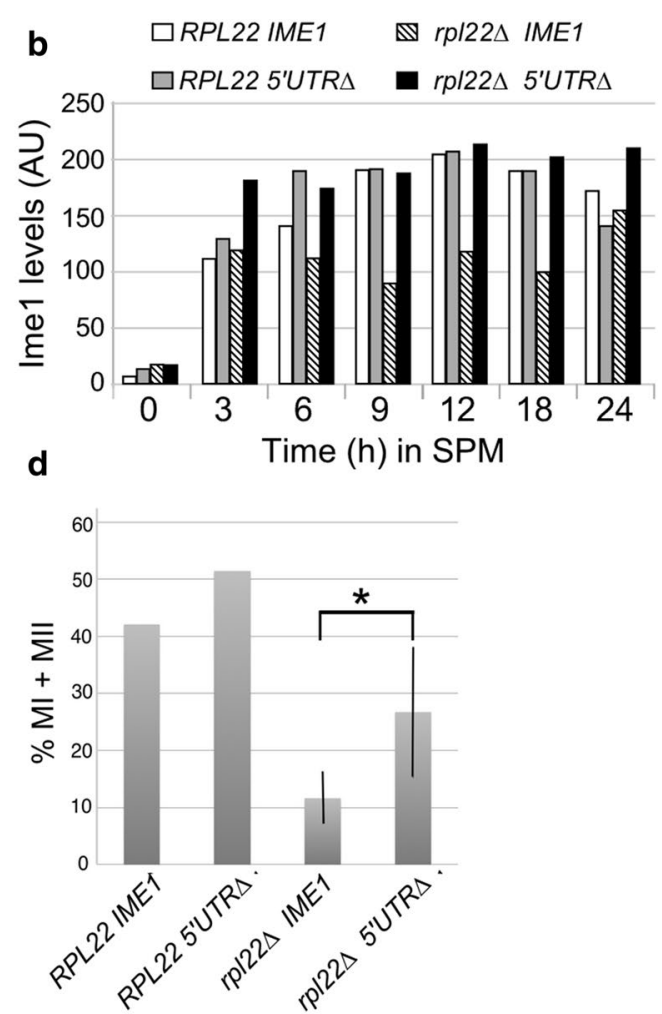

Fig. 5 Rpl22 supports translation through the IME1 5'UTR. a Western blot analysis of protein samples prepared from wild type (RSY1833, RSY1991) and rp/22 $\triangle$ double mutant (RSY1839, RSY1993) strains harboring IME1-3HA or 5'UTRA-IME1 alleles, respectively. The blots were probed for Ime1-3HA and Pgk1, which served as a loading control. b The Ime1 signals obtained in a were quantified, normalized to Pgk1 levels, and plotted for each timepoint (see "Methods" section for details). c IME2 mRNA levels were determined by qRT-PCR during a meiotic timecourse with the strains described in $\mathbf{a}$. The results depicted are the average from three technical replicates from one experiment. $\mathbf{d}$ Terminal sporulation efficiencies following $24 \mathrm{~h}$ in SPM were determined for the strains described in $\mathbf{a}$. The values for $r p / 22 \Delta$ and $5^{\prime} U T R \Delta-I M E 1$ are the result of two trials of three independent cultures. Error bars indicate SEM. Asterisk indicates $p=0.05$

wild-type and rpl22 cells $12 \mathrm{~h}$ after shifting to sporulation medium (Fig. 6e). Interestingly, meiotic rpl22 $2 \Delta$ cells did not exhibit the halfmer phenotype as the free $40 \mathrm{~S}$ and $60 \mathrm{~S}$ subunit peaks in both sporulating wild type or rpl22A cells were largely absent. One possibility is that idle ribosomal subunits are catabolized upon entry into meiosis, relieving "halfmer" formation in polysome peaks. Since normal profiles were obtained from meiotic $r p l 22 \Delta$ cells, these results suggest that the halfmer formation and the failure to translate $I M E 1$ mRNA represent separate phenotypes associated with loss of Rpl22 function.

\section{Discussion}

Changes in cell fate require remodeling the gene expression program at the level of both transcription and translation [12, 40]. Although transcriptional control has been the focus of extensive study, it is becoming increasing clear that regulated translation also mediates these decisions. In this report, we demonstrate that the non-essential large subunit ribosomal protein Rpl22 is required for the developmental switch from normal mitotic cell division to either invasive/pseudohyphal growth or meiotic entry. As meiosis and hyphal growth are induced under conditions of limiting or depleted environmental nitrogen, Rpl22 may represent a mediator of low-nitrogen dependent translation. To promote meiotic induction, Rpl22 is necessary for efficient translation of the meiotic inducer IME1 mRNA. Importantly, the requirement of Rpl22 for IME1 mRNA translation can be suppressed by deleting the unusually long IME1 $5^{\prime}$ UTR. Formally, these results indicate that Rpl22 operates through this region. However, only partial restoration of sporulation efficiency was observed in the rpl22 2 mutant expressing IME1 lacking the $5^{\prime}$ UTR suggesting that additional execution points for Rpl22 exist during meiosis. Taken together, these results suggest that Rpl22 is the target of a late nitrogen checkpoint. Once this checkpoint is satisfied, Rpl22 is activated allowing efficient IME1 mRNA translation by overriding 5'UTR-mediated inhibition. 

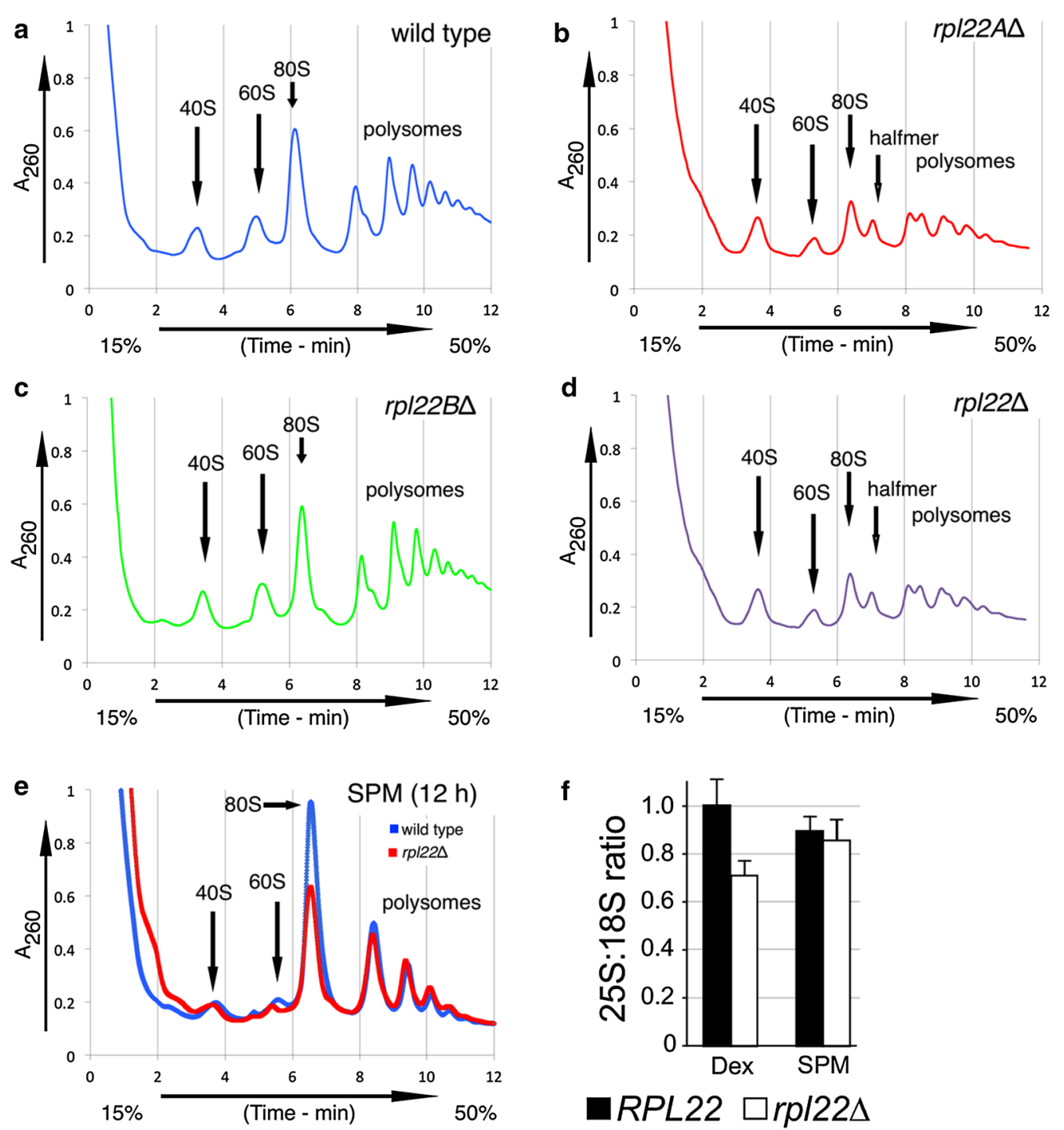

- RPL22 $\square r p / 22 \Delta$

Fig. 6 Rpl22 is required for normal polysome profiles under conditions of high translational output. a Logarithmically growing wild type (RSY335),

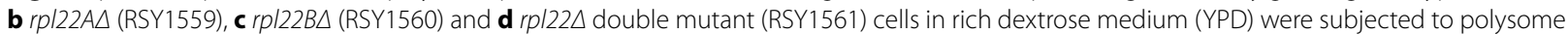
profile analysis through sucrose density gradient centrifugation. The arrows indicate the 40S, 60S, 805 monosome and halfmer positions. e Overlaid polysome profiles for wild type and $r$ / $22 \Delta$ strains taken $9 \mathrm{~h}$ following transfer to SPM medium. f The 25S:18S rRNA ratios were quantified by Northern blot analysis for wild type and the rpl22 $\Delta$ double mutant in log phase cells grown in rich dextrose (YPD) medium. The cumulative differences between the $25 \mathrm{~S}: 18 \mathrm{~S}$ ratios in wild type and rp/22 $\Delta$ double mutant strains were significantly different $(p=0.02)$ in YPD but not SPM

In metazoans, L22 is involved in B- and T-cell differentiation and suppressing T-cell transformation [41-43], reviewed in [41]. Based on these reports and results described here, the regulation and function of yeast and vertebrate Rpl22 share both similarities and differences. Neither yeast nor vertebrate Rpl22 are required for bulk translation while both control cell differentiation events. However, unlike vertebrate Rpl22 and Rpl22-like1 that exhibit both overlapping and antagonistic activities, the yeast Rpl22 paralogs have similar functions with Rpl22A being more active. These results are most likely explained by the higher RPL22A expression levels compared to $R P L 22 B$ [32]. In mice and zebrafish, Rpl22 antagonizes the expression of Rpl22-like1 [24] while deleting RPL22A results in increased $R P L 22 B$ transcription. Finally, vertebrate $\mathrm{Rpl} 22$ controls developmental process through translation independent mechanisms. In yeast, although a non-translational role for Rpl22A has been reported that helps target specific mRNAs to the bud [32], we find that Rpl22 mediates meiotic entry by translational control of IME1.

We identified a strong halfmer phenotype in rpl22A mutants growing in rich medium. Mutations in another 


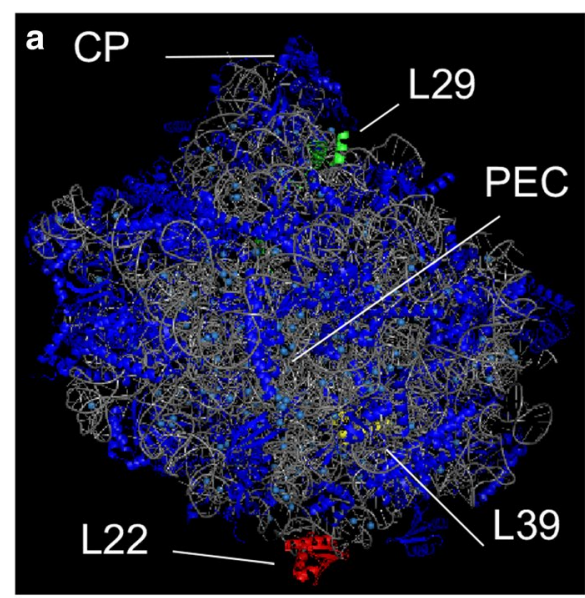

b

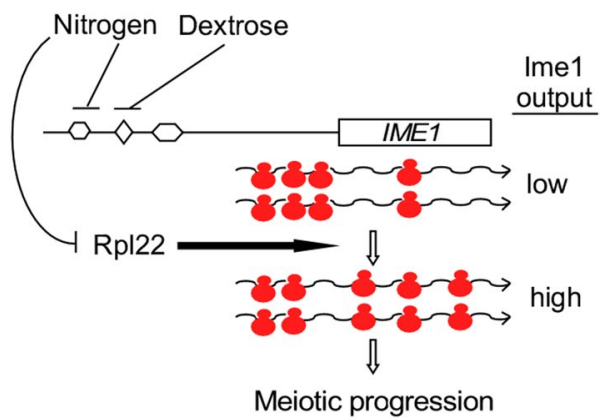

Fig. 7 Model for Rpl22 function. a Location of Rpl22 (red), Rpl29 (green), Rpl39 (yellow), central protuberance (CP) and peptide exit channel (PEC) are indicated. b Cartoon of IMEI gene structure with upstream promoter elements repressed by dextrose or nitrogen. Ribosome stalling on the 5'UTR is indicated resulting in low Ime 1 production. Release of Rpl22 activity from nitrogen repression allows full IME1 mRNA translation and increased Ime1 production sufficient for meiotic progression. a Large subunit structure adapted from [16]

large subunit ribosomal protein, Rpl29, also demonstrates a "halfmer" phenotype [34]. However, unlike rpl22 2 mutants, $r p l 29 \Delta$ strains do not exhibit a reduction in free $60 \mathrm{~S}$ subunit accumulation. The finding that Rpl29 is located on the $40 \mathrm{~S}$ interaction face of the large subunit (Fig. 7a) is consistent with a stabilizing role in subunit association. Conversely, we find that Rpl22 is required to maintain the normal $60 \mathrm{~S}: 40 \mathrm{~S}$ ratio suggesting that loss of $60 \mathrm{~S}$ subunit concentration contributes to this phenotype. This possibility is supported by the finding that the halfmer population and the $60 \mathrm{~S}: 40 \mathrm{~S}$ imbalance is largely missing in rpl22 $\Delta$ sporulating cultures. These results suggest that the IME1 mRNA translation defect and the halfmer phenotype are most likely independent events. How does Rpl22 enhance $60 \mathrm{~S}$ subunit stability? Rpl22 is located away from $40 \mathrm{~S}$ interaction and binds the $25 \mathrm{~S}$ rRNA (Fig. 7a). Therefore, one model is that Rpl22 assists
$60 S$ subunit assembly by interacting with the rRNA. Alternatively, its role may be in subunit maintenance by protecting the $25 \mathrm{~S}$ rRNA from nuclease attack. These two activities are not mutually exclusive leaving open the possibility that the reduction in $60 \mathrm{~S}$ subunit concentration is the result of multiple factors. Regardless of the mechanism, this phenotype only occurs in rapidly dividing cells that normally maintain high levels of free subunits to accommodate elevated translation rates. This may suggest that Rpl22 is not involved in 60S stability when part of the $80 \mathrm{~S}$ particle. Understanding how the cell adjusts free subunit content based on high or low metabolism will provide insight into this question.

Gene transcription is regulated by signaling networks responding to both intrinsic and extrinsic stimuli [44]. Similarly, IME1 transcription is controlled by the PKA and TOR signaling pathways that monitor the nutritional status of the cell [45-48]. IME1 transcription displays three regulatory states namely off, low and high-level expression [49]. These states indicate cellular conditions of mitotic cell division, conditions permissive to enter meiosis or meiotic induction itself, respectively. We find a similar tiered structure for IME1 mRNA translation as well. Cells growing in the absence of glucose but still sensing nitrogen fail to translate IME1 mRNA although the transcript is present (compare $0 \mathrm{~h}$ timepoints, Figs. 3, 5). Transfer to sporulation medium induces a low level of IME1 mRNA translation (3-6 h, Fig. 5). Ime1 levels then elevate $(9-12 \mathrm{~h})$ to a threshold sufficient to induce Ume6 destruction and subsequent induction of early meiotic genes such as IME2. However, this induction step requires Rpl22 placing specialized translation into the meiotic induction pathway. These results suggest a model that the nitrogen signal inhibits Rpl22 function thus preventing Ime1 accumulation to a level sufficient to induce meiosis (Fig. 7b). Only when the nitrogen signal is completely removed does Rpl22 become fully functional. Consistent with this model, four phosphorylation sites on Rpl22 have been mapped including potential MAPK/ $\mathrm{Cdk}$ and caseine kinase recognition sites. This step may provide the cell another safeguard to insure that conditions are correct to enter meiosis. It has been previously described that the small subunit and translation initiation factors receive signals that control the initiation process [50-52]. Our results suggest that the large ribosomal subunit is also a recipient of such signals, allowing increased translational efficiency of developmental mRNAs.

Our results indicate that $\mathrm{Rpl} 22$ mediates IME1 mRNA translation through its large $5^{\prime} \mathrm{UTR}$. This result is consistent with previous studies that identified this region as important for meiotic translation $[10,11]$. The $5^{\prime} \mathrm{UTR}$ is an important regulatory element in the translation of developmentally regulated loci such as the HOX genes in 
vertebrates [53, 54]. In the case of HOXa5 and HOXa9, the $5^{\prime}$ UTR utilizes an internal ribosome entry site (IRES) through an Rpl38-dependent mechanism. In addition to meiosis, we demonstrate that Rpl22 is required for both invasive and pseudohyphal growth. Two genes required for these processes (FLO8, FLO11) also possess long 5'UTRs that utilize IRES elements for translation [55]. These observations reveal a possible role for Rpl22 in IRES utilization. This possibility is supported by the finding that Rpl22 enhances IRES mediated translation in the hepatitis C virus $3^{\prime} \mathrm{UTR}$ [56].

Another mechanism by which the $5^{\prime} \mathrm{UTR}$ restricts translation is through the presence of short upstream open reading frames (uORFs) [12]. Scanning 40S subunits recognize these $\mathrm{uORFs}$ and initiate translation only to terminate the process after a short peptide is generated $[15,57]$. The IME1 $5^{\prime} \mathrm{UTR}$ does not contain any uORFs with the canonical AUG start codon. However, a previous study identified ribosomal pausing sites within meiotic $5^{\prime}$ UTRs that contain proposed non-canonical sites (e.g., CUG, AUU, GUG) [57]. Examination of the IME1 $5^{\prime}$ UTR revealed several of these sequences suggesting the possibility that IME1 mRNA translation may be regulated by ribosome pausing. This possibility is supported by the finding that ribosomal pausing is observed at the $5^{\prime} \mathrm{UTR}$ in IME1 mRNA early in development but is lost as cells progress through meiosis [57], see Fig. 7b). As would be predicted, ribosome release from the $5^{\prime}$ UTR occurs coincident with Ime1 protein appearance and the Rpl22 execution point. This model is consistent with our results revealing an initial low-level accumulation of Ime1 followed by a rapid elevation in protein concentration that is dependent on Rpl22.

\section{Conclusion}

Rpl22 is a conserved component of the eukaryotic ribosome that carries out specialized functions in many organisms. We find that Rpl22 is required for adopting hyphal growth characteristics and meiotic entry in S. cerevisiae. The latter role is due to Rpl22-dependent translation of the meiotic inducer IME1 mRNA.

\footnotetext{
Abbreviations

mRNA: messenger RNA; UTR: untranslated region; UORF: upstream open reading frame; IRES: internal ribosome entry sites; $\mathrm{CHX}$ : cycloheximide; qRT-PCR: quantitative reverse transcriptase-polymerase chain reaction; DAPI: 4',6-diamidino-2-phenylindole; YPA: yeast extract peptone acetate; YPD: yeast extract peptone dextrose; SPM: sporulation medium; AMV-RT: avian myeloblastosis virus-reverse transcriptase; DEPC: diethylpyrocarbonate; EDTA: ethylenediaminetetraacetic acid; SLAD: synthetic, low-ammonia, dextrose; PVDF: polyvinylidene fluoride; RP: ribosomal proteins.
}

\section{Authors' contributions}

SJK carried out the meiotic mRNA expression experiments, ribosome polysome profiling, analysis of hyphal growth studies, analyzed the data and drafted the manuscript. RS conceived the study, performed phenotypic studies of rp/22 2 null alleles, analyzed the data and edited the manuscript. Both authors read and approved the final manuscript.

\section{Acknowledgements}

We thank Dr. Dmitri Pestov and Dr. Katrina F. Cooper for helpful discussions with this work. We also thank Dr. Dmitri Pestov and Dr. Natalia Shcherbik for expert help with the polysome profiling analysis.

\section{Competing interests}

The authors declare that they have no competing interests.

\section{Availability of data and materials}

All novel reagents described in this manuscript will be freely available to academic scientists.

\section{Funding}

This work was supported by a grant from the National Institutes of Health (GM086788) to R.S

Received: 25 May 2016 Accepted: 8 July 2016

Published online: 29 July 2016

\section{References}

1. Song Q, Kumar A. An overview of autophagy and yeast pseudohyphal growth: integration of signaling pathways during nitrogen stress. Cells. 2012:1:263-83.

2. Zaragoza O, Gancedo JM. Pseudohyphal growth is induced in Saccharomyces cerevisiae by a combination of stress and cAMP signalling. Antonie Van Leeuwenhoek. 2000;78:187-94.

3. Gimeno CJ, Fink GR. Induction of pseudohyphal growth by overexpression of PHD1, a Saccharomyces cerevisiae gene related to transcriptional regulators of fungal development. Mol Cell Biol. 1994;14:2100-12.

4. Gimeno CJ, Ljungdahl PO, Styles CA, Fink GR. Unipolar cell divisions in the yeast $S$. cerevisiae lead to filamentous growth: regulation by starvation and RAS. Cell. 1992;68:1077-90.

5. Winter E. The Sum $1 / \mathrm{Ndt} 80$ transcriptional switch and commitment to meiosis in Saccharomyces cerevisiae. Microbiol Mol Biol Rev. 2012;76:1-15.

6. Mallory MJ, Cooper KF, Strich R. Meiosis-specific destruction of the Ume6p repressor by the Cdc20-directed APC/C. Mol Cell. 2007;27:951-61.

7. Strudwick N, Brown M, Parmar VM, Schroder M. Ime1 and Ime2 are required for pseudohyphal growth of Saccharomyces cerevisiae on nonfermentable carbon sources. Mol Cell Biol. 2010;30:5514-30.

8. Kassir Y, Adir N, Boger-Nadjar E, Raviv NG, Rubin-Bejerano I, Sagee S, Shenhar G. Transcriptional regulation of meiosis in budding yeast. Int Rev Cytol. 2003:224:111-71.

9. Kahana S, Pnueli L, Kainth P, Sassi HE, Andrews B, Kassir Y. Functional dissection of IME1 transcription using quantitative promoter-reporter screening. Genetics. 2010;186:829-41.

10. Sherman A, Shefer M, Sagee S, Kassir Y. Post-transcriptional regulation of IME1 determines initiation of meiosis in Saccharomyces cerevisiae. Mol Gen Genet. 1993;237:375-84.

11. Mitchell AP. Control of meiotic gene expression in Saccharomyces cerevisiae. Microbiol Rev. 1994;58:56-70.

12. Sonenberg N, Hinnebusch AG. Regulation of translation initiation in eukaryotes: mechanisms and biological targets. Cell. 2009;136:731-45.

13. Costello J, Castelli LM, Rowe W, Kershaw CJ, Talavera D, MohammadQureshi SS, Sims PF, Grant CM, Pavitt GD, Hubbard SJ, Ashe MP. Global mRNA selection mechanisms for translation initiation. Genome Biol. 2015;16:10.

14. Holcik M, Sonenberg N. Translational control in stress and apoptosis. Nat Rev Mol Cell Biol. 2005;6:318-27.

15. Ingolia NT, Ghaemmaghami S, Newman JRS, Weissman JS. Genome-wide analysis in vivo of translation with nucleotide resolution using ribosome profiling. Science. 2009;324:218-23.

16. Klinge S, Voigts-Hoffmann F, Leibundgut M, Arpagaus S, Ban N. Crysta structure of the eukaryotic 605 ribosomal subunit in complex with initiation factor 6. Science. 2011:334:941-8. 
17. Yusupova G, Yusupov M. High-resolution structure of the eukaryotic 805 ribosome. Annu Rev Biochem. 2014;83:467-86.

18. Steffen KK, McCormick MA, Pham KM, MacKay VL, Delaney JR, Murakami CJ, Kaeberlein M, Kennedy BK. Ribosome deficiency protects against ER stress in Saccharomyces cerevisiae. Genetics. 2012;191:107-18.

19. Lecompte O, Ripp R, Thierry JC, Moras D, Poch O. Comparative analysis of ribosomal proteins in complete genomes: an example of reductive evolution at the domain scale. Nucleic Acids Res. 2002;30:5382-90.

20. O'Leary MN, Schreiber KH, Zhang Y, Duc AC, Rao S, Hale JS, Academia EC, Shah SR, Morton JF, Holstein CA, et al. The ribosomal protein Rpl22 controls ribosome composition by directly repressing expression of its own paralog, Rpl2211. PLoS Genet. 2013;9:e1003708.

21. Costanzo M, Baryshnikova A, Bellay J, Kim Y, Spear ED, Sevier CS, Ding H, Koh JL, Toufighi K, Mostafavi S, et al. The genetic landscape of a cell. Science. 2010;327:425-31.

22. Dobbelstein $M$, Shenk T. In vitro selection of RNA ligands for the ribosomal L22 protein associated with Epstein-Barr virus-expressed RNA by using randomized and cDNA-derived RNA libraries. J Virol. 1995;69:8027-34.

23. Anderson SJ, Lauritsen JP, Hartman MG, Foushee AM, Lefebvre JM, Shinton SA, Gerhardt B, Hardy RR, Oravecz T, Wiest DL. Ablation of ribosomal protein L22 selectively impairs alphabeta T cell development by activation of a p53-dependent checkpoint. Immunity. 2007;26:759-72.

24. Zhang Y, Duc AC, Rao S, Sun XL, Bilbee AN, Rhodes M, Li Q, Kappes DJ, Rhodes J, Wiest DL. Control of hematopoietic stem cell emergence by antagonistic functions of ribosomal protein paralogs. Dev Cell. 2013;24:411-25

25. Kearse MG, Ireland JA, Prem SM, Chen AS, Ware VC. RpL22e, but not RpL22e-like-PA, is SUMOylated and localizes to the nucleoplasm of Drosophila meiotic spermatocytes. Nucleus. 2013;4:241-58.

26. Sikorski RS, Hieter P. A system of shuttle vectors and yeast host strains designed for efficient manipulation of DNA in Saccharomyces cerevisiae. Genetics. 1989:122:19-27.

27. Cooper KF, Mallory MJ, Smith JB, Strich R. Stress and developmental regulation of the yeast C-type cyclin Ume3p (Srb1 1p/Ssn8p). EMBO J. 1997;16:4665-75

28. Kushnirov VV. Rapid and reliable protein extraction from yeast. Yeast. 2000;16:857-60

29. Kamada Y, Jung US, Piotrowski J, Levin DE. The protein kinase C-activated MAP kinase pathway of Saccharomyces cerevisiae mediates a novel aspect of the heat shock response. Genes Dev. 1995;9:1559-71.

30. Sagliocco FA, Moore PA, Brown AJ. Polysome analysis. Methods Mol Biol. 1996;53:297-311.

31. Pestov DG, Shcherbik N. Rapid cytoplasmic turnover of yeast ribosomes in response to rapamycin inhibition of TOR. Mol Cell Biol. 2012:32:2135-44.

32. Komili S, Farny NG, Roth FP, Silver PA. Functional specificity among ribosomal proteins regulates gene expression. Cell. 2007;131:557-71.

33. Parenteau J, Durand M, Morin G, Gagnon J, Lucier JF, Wellinger RJ, Chabot B, Elela SA. Introns within ribosomal protein genes regulate the production and function of yeast ribosomes. Cell. 2011;147:320-31.

34. DeLabre ML, Kessl J, Karamanou S, Trumpower BL. RPL29 codes for a nonessential protein of the $60 \mathrm{~S}$ ribosomal subunit in Saccharomyces cerevisiae and exhibits synthetic lethality with mutations in genes for proteins required for subunit coupling. Biochim Biophys Acta. 2002:1574:255-61.

35. Peisker K, Braun D, Wolfle T, Hentschel J, Funfschilling U, Fischer G, Sickmann A, Rospert S. Ribosome-associated complex binds to ribosomes in close proximity of Rpl31 at the exit of the polypeptide tunnel in yeast. Mol Biol Cell. 2008;19:5279-88.

36. Mallory MJ, Law MJ, Sterner DE, Berger SL, Strich R. Gcn5p-dependent acetylation induces degradation of the meiotic transcriptional repressor Ume6p. Mol Biol Cell. 2012;23:1609-17.

37. Babiano R, Gamalinda M, Woolford JL Jr, de la Cruz J. Saccharomyces cerevisiae ribosomal protein $\mathrm{L} 26$ is not essential for ribosome assembly and function. Mol Cell Biol. 2012;32:3228-41.

38. Robledo S, Idol RA, Crimmins DL, Ladenson JH, Mason PJ, Bessler M. The role of human ribosomal proteins in the maturation of rRNA and ribosome production. RNA. 2008;14:1918-29.

39. Rosado IV, Kressler D, de la Cruz J. Functional analysis of Saccharomyces cerevisiae ribosomal protein Rpl3p in ribosome synthesis. Nucleic Acids Res. 2007;35:4203-13.
40. Spriggs KA, Stoneley M, Bushell M, Willis AE. Re-programming of translation following cell stress allows IRES-mediated translation to predominate. Biol Cell. 2008:100:27-38.

41. Fahl SP, Wang M, Zhang Y, Duc AC, Wiest DL. Regulatory roles of Rpl22 in hematopoiesis: an old dog with new tricks. Crit Rev Immunol. 2015;35:379-400

42. Rao S, Lee SY, Gutierrez A, Perrigoue J, Thapa RJ, Tu Z, Jeffers JR, Rhodes $M$, Anderson S, Oravecz T, et al. Inactivation of ribosomal protein $L 22$ promotes transformation by induction of the stemness factor, Lin28B. Blood. 2012;120:3764-73.

43. Stadanlick JE, Zhang Z, Lee SY, Hemann M, Biery M, Carleton MO, Zambetti GP, Anderson SJ, Oravecz T, Wiest DL. Developmental arrest of T cells in Rpl22-deficient mice is dependent upon multiple p53 effectors. J Immunol. 2011;187:664-75.

44. Borggrefe T, Lauth M, Zwijsen A, Huylebroeck D, Oswald F, Giaimo BD. The Notch intracellular domain integrates signals from Wnt, Hedgehog, TGF $\beta /$ BMP and hypoxia pathways. Biochim Biophys Acta. 2016;1863:303-13.

45. Honigberg SM, Purnapatre K. Signal pathway integration in the switch from the mitotic cell cycle to meiosis in yeast. J Cell Sci. 2003;116:2137-47.

46. Colomina N, Gari E, Gallego C, Herrero E, Aldea M. G1 cyclins block the Ime1 pathway to make mitosis and meiosis incompatible in budding yeast. EMBO J. 1999;18:320-9.

47. Deng C, Saunders WS. RIM4 encodes a meiotic activator required for early events of meiosis in Saccharomyces cerevisiae. Mol Genet Genomics. 2001;266:497-504.

48. Valbuena N, Moreno S. TOR and PKA pathways synergize at the level of the Ste 11 transcription factor to prevent mating and meiosis in fission yeast. PLoS One. 2010;5:e11514.

49. Purnapatre K, Piccirillo S, Schneider BL, Honigberg SM. The CLN3/SWI6/ CLN2 pathway and SNF1 act sequentially to regulate meiotic initiation in Saccharomyces cerevisiae. Genes Cells. 2002;7:675-91.

50. Magnuson B, Ekim B, Fingar DC. Regulation and function of ribosomal protein $\mathrm{S} 6$ kinase (S6K) within mTOR signalling networks. Biochem J. 2012:441:1-21.

51. Powers T. TOR signaling and S6 kinase 1: yeast catches up. Cell Metab. 2007:6:1-2.

52. Ruvinsky I, Meyuhas O. Ribosomal protein $\mathrm{S} 6$ phosphorylation: from protein synthesis to cell size. Trends Biochem Sci. 2006;31:342-8.

53. Kondrashov N, Pusic A, Stumpf CR, Shimizu K, Hsieh AC, Xue S, Ishijima J, Shiroishi T, Barna M. Ribosome-mediated specificity in Hox mRNA translation and vertebrate tissue patterning. Cell. 2011;145:383-97.

54. Xue S, Tian S, Fujii K, Kladwang W, Das R, Barna M. RNA regulons in Hox $5^{\prime}$ UTRs confer ribosome specificity to gene regulation. Nature. 2015;517:33-8

55. Gilbert WV, Zhou K, Butler TK, Doudna JA. Cap-independent translation is required for starvation-induced differentiation in yeast. Science. 2007:317:1224-7.

56. Wood J, Frederickson RM, Fields S, Patel AH. Hepatitis $C$ virus $3^{\prime} X$ region interacts with human ribosomal proteins. J Virol. 2001;75:1348-58.

57. Brar GA, Yassour M, Friedman N, Regev A, Ingolia NT, Weissman JS. High-resolution view of the yeast meiotic program revealed by ribosome profiling. Science. 2012;335:552-7.

\section{Submit your next manuscript to BioMed Central and we will help you at every step:}

- We accept pre-submission inquiries

- Our selector tool helps you to find the most relevant journal

- We provide round the clock customer support

- Convenient online submission

- Thorough peer review

- Inclusion in PubMed and all major indexing services

- Maximum visibility for your research

Submit your manuscript at www.biomedcentral.com/submit 